\title{
Henneguya cuniculator sp. nov., a parasite of spotted sorubim Pseudoplatystoma corruscans in the São Francisco Basin, Brazil
}

\author{
Juliana Naldoni ${ }^{1}$, Antônio A. M. Maia ${ }^{2, *}$, Marcia R. M. da Silva ${ }^{2}$, \\ Edson A. Adriano ${ }^{1,3}$ \\ ${ }^{1}$ Departamento de Biologia Animal da Universidade Estadual de Campinas (UNICAMP), Rua Monteiro Lobato, 255, \\ CEP 13083-970, Campinas, Sao Paulo, Brazil \\ ${ }^{2}$ Departamento de Ciências Básicas, Faculdade de Zootecnia e Engenharia de Alimentos, Universidade de São Paulo (USP), \\ Rua Duque de Caxias Norte, 225, CEP 13635-900, Pirassununga, Sao Paulo, Brazil \\ ${ }^{3}$ Departamento de Ciências Biológicas, Universidade Federal de São Paulo (UNIFESP), Rua Professor Artur Riedel, 275 , \\ Jardim Eldorado, CEP 09972-270, Diadema, Sao Paulo, Brazil
}

\begin{abstract}
Henneguya cuniculator sp. nov. was found infecting spotted sorubim catfish Pseudoplatystoma corruscans from the São Francisco River, Minas Gerais, Brazil. The parasites form elongated plasmodia of up to $1 \mathrm{~cm}$ in length in the gill filaments. Mature spores were ellipsoidal from the frontal view, with total length of $29.4 \pm 2.4$ (mean $\pm \mathrm{SD}$, range 23.3-32.4) $\mu \mathrm{m}$, body length of $12.1 \pm 1.0(10.0-14.7) \mu \mathrm{m}$, width of $4.8 \pm 0.4(4.0-5.9) \mu \mathrm{m}$, and tail length of $16.7 \pm 2.0(12.3-19.4) \mu \mathrm{m}$. From the lateral view, spores were biconvex, with thickness of $4.2 \pm 0.7(3.9-4.9) \mu \mathrm{m}$. The polar capsules were elongated and equal in size, $6.2 \pm 0.3(5.2-6.2) \mu \mathrm{m}$ in length, and $1.8 \pm 0.1(1.4-1.9) \mu \mathrm{m}$ in width. Ultrastructural analysis showed that the plasmodial wall had delicate projections towards the host tissue and a thin layer that prevented contact between the host cells and the parasite. In the ectoplasm, few mitochondria were observed, while generative cells, early stages of sporogenesis, and advanced spore development occurred in the plasmodial periphery, and more mature spores in internal regions. Histopathological analysis showed that plasmodia developed in the sub-epithelial connective tissue of gill filaments, causing compression of the adjacent tissues, deformation of gill filaments, and lamellar fusion. Phylogenetic analysis, based on 18S rDNA genes and using only Henneguya/Myxobolus species parasites of siluriform fish, showed grouping according to the fish family.
\end{abstract}

KEY WORDS: Myxozoa $\cdot$ Pseudoplatystoma $\cdot$ São Francisco River $\cdot 18 \mathrm{~S}$ rDNA $\cdot$ Ultrastructure

\section{INTRODUCTION}

The spotted sorubim Pseudoplatystoma corruscans (Spix \& Agassiz, 1829), popularly known in Brazil as 'pintado' or 'surubim,' is a catfish siluriform of the family Pimelodidae. It is found in the La Plata and São Francisco Basins of South America (Resende 2003). These carnivorous, migratory fish can reach up to $160 \mathrm{~cm}$ in length and $100 \mathrm{~kg}$ in weight (Froese
\& Pauly 2011), and due to the high quality of their meat, they play an important role in the fishing economy of the regions in which they are found (Campos 2005). P. corruscans is important for Brazilian aquaculture, as fingerlings created by crossbreeding of this species with $P$. reticulatum Eigenmann \& Eigenmann, 1889 are reared in fish farms across the country (Naldoni et al. 2009). This hybrid fish is called 'pintado,' and its production in Brazilian fish farms 
reached $2486 \mathrm{t}$ in 2010 (MPA 2012). It is sold in the Brazilian market, and is also exported to several countries (Mar \& Terra 2013).

The first report of a fish of the genus Pseudoplatystoma infected with a myxosporean was made by Eiras et al. (2009), who described Henneguya corruscans Eiras et al., 2009, infecting P. corruscans from the Paraná River. Since then, 5 other species have been described: H. pseudoplatystoma Naldoni et al., 2009, was found infecting hybrid pintado taken from fish farms in the states of São Paulo and Mato Grosso do Sul, and H. eirasi Naldoni et al., 2011, H. multiplasmodialis Adriano et al., 2012, Henneguya m. Carriero et al., 2013, and Myxobolus flavus Carriero et al., 2013, were found infecting both $P$. corruscans and $P$. reticulatum taken from natural environments in the Brazilian Pantanal wetland (Naldoni et al. 2009, 2011, Adriano et al. 2012, Carriero et al. 2013).

All myxozoan species described herein as occurring in Pseudoplatystoma spp. are from the La Plata Basin. We used morphologic, histologic, ultrastructural, and 18S rDNA sequencing data to describe a new Henneguya species that parasitizes the gill filaments of Pseudoplatystoma corruscans from natural environments in the São Francisco Basin.

\section{MATERIALS AND METHODS}

Ten specimens of Pseudoplatystoma corruscans (ranging from 56 to $93 \mathrm{~cm}$ in length) were collected from the São Francisco River $\left(17^{\circ} 12^{\prime} 8^{\prime \prime} \mathrm{S}\right.$, $44^{\circ} 50^{\prime} 0^{\prime \prime} \mathrm{W}$ ) in the municipality of Pirapora, state of Minas Gerais, Brazil. These samples were collected in July $(\mathrm{n}=4)$ and December $2011(\mathrm{n}=6)$. After capture, the fish were transported alive to the laboratory, where they were euthanized by benzocaine overdose (methodology approved by the ethics research committee of the Universidade Estadual de Campinas proc. no. 2334-1), in accordance with Brazilian law (Federal Law No. 11.794, dated 8 October 2008 and Federal Decree No. 6899, dated 15 July 2009). The fish were then measured and necropsied. Plasmodia with mature spores were examined in fresh mounts with a light microscope. Morphological characterization of the spores was based on mature spores obtained from 3 different specimens. Measurements were performed on 30 spores using a computer equipped with Axivision 4.1 image capture software coupled to an Axioplan 2 Zeiss microscope. The dimensions of the spores are expressed as mean \pm $\mathrm{SD}$, in $\mu \mathrm{m}$. Smears containing free spores were airdried and stained with Giemsa solution and mounted in a low-viscosity mounting medium (CytosealTM) on permanent slides.

For histological analysis, fragments of infected organs were fixed in $10 \%$ buffered formalin and embedded in paraffin. Serial sections with a thickness of $4 \mu \mathrm{m}$ were stained with hematoxylin-eosin.

For transmission electron microscopy, plasmodia were fixed in $2.5 \%$ glutaraldehyde in $0.1 \mathrm{M}$ sodium cacodylate buffer $(\mathrm{pH}$ 7.4) for $12 \mathrm{~h}$, washed in a glucose-saline solution for $2 \mathrm{~h}$, and post-fixed in $\mathrm{OsO}_{4}$. All of these processes were performed at $4{ }^{\circ} \mathrm{C}$. After dehydration using an acetone series, the material was embedded in EMbed 812 resin. Semithin sections were stained with toluidine blue solution and examined by light microscopy. Ultrathin sections, double stained with uranyl acetate and lead citrate, were examined in an LEO 906 electron microscope at $60 \mathrm{kV}$.

For molecular study, plasmodia were removed from the host tissue and fixed in absolute ethanol. The plasmodium content was collected in a $1.5 \mathrm{ml}$ microcentrifuge tube and the DNA was extracted using the DNeasy ${ }^{\circledR}$ Blood \& Tissue kit (Qiagen), following the manufacturer's instructions. The product was quantified in a NanoDrop 2000 spectrophotometer (Thermo Scientific) at $260 \mathrm{~nm}$. PCR was carried out using a final volume of $25 \mu \mathrm{l}$, which contained 10 to $50 \mathrm{ng}$ of extracted DNA, 1× Taq DNA polymerase buffer, $0.2 \mathrm{mmol}$ of dNTP, $1.5 \mathrm{mmol}$ of $\mathrm{MgCl}_{2}, 0.2 \mathrm{pmol}$ of each primer, $0.25 \mu \mathrm{l}(1.25 \mathrm{U})$ of Taq DNA polymerase (all reagents from Invitrogen by Life Technologies), and MilliQ (EMD Millipore) purified water in an Eppendorf AG 22331 Hamburg Thermocycler. Fragments of $1000 \mathrm{bp}$ were amplified using the primers ERIB1+ACT1R (Barta et al. 1997), and fragments of $1200 \mathrm{bp}$ were amplified using the primers MYXGEN+ERIB10 (Hallett \& Diamant 2001, Diamant et al. 2004). An initial denaturation step at $95^{\circ} \mathrm{C}$ for $5 \mathrm{~min}$ was followed by 35 cycles of denaturation $\left(95^{\circ} \mathrm{C}\right.$ for $\left.60 \mathrm{~s}\right)$, annealing $\left(62^{\circ} \mathrm{C}\right.$ for $\left.60 \mathrm{~s}\right)$, and extension $\left(72^{\circ} \mathrm{C}\right.$ for $\left.120 \mathrm{~s}\right)$; finishing with an extended elongation step at $72^{\circ} \mathrm{C}$ for 5 min. PCR products were electrophoresed in $1.0 \%$ agarose gel, stained with ethidium bromide, and analyzed in an FLA-3000 scanner (Fuji Photo Film). The size of the amplicons was estimated by comparison with the $1 \mathrm{~kb}$ DNA Ladder (Invitrogen by Life Technologies). Purified PCR products were sequenced using the same primer pair that was used in the amplification step, and another primer pair MC5-MC3 (Eszterbauer 2004) with the BigDye ${ }^{\circledR}$ Terminator v3.1 Cycle Sequencing kit (Applied Biosystems ${ }^{\mathrm{TM}}$ ) in an ABI 3730 DNA Analyzer (Applied Biosystems ${ }^{\mathrm{TM}}$ ). A stan- 
dard nucleotide-nucleotide BLAST (blastn) search was conducted to verify the similarity of the sequence obtained in this study with other sequences available in the GenBank database (Altschul et al. 1997).

Phylogenetic analysis was performed using only myxosporean parasites of siluriforms available from GenBank. This included 13 sequences of Henneguya species and 2 sequences of Myxobolus species. Ceratomyxa shasta and C. seriolae were used as the outgroup. Nucleotide sequences were aligned using ClustalW inserted in BioEdit version 7.0.9.0 (Hall 1999). The Jmodeltest 0.1 program (Posada 2008) was used to choose the best evolution model of the sequences, and selected the GRT+G model. Nucleotide frequencies were estimated from the data $(\mathrm{A}=$ $0.2500, \mathrm{C}=0.2105, \mathrm{G}=0.2879, \mathrm{~T}=0.2116)$. The 6 rates of nucleotide substitution were $(\mathrm{AC})=0.8263$, $(\mathrm{AG})=2.2627,(\mathrm{AT})=1.1733,(\mathrm{CG})=0.6128,(\mathrm{CT})=$ $4.2650,(\mathrm{GT})=1.0000$, gamma shape $=0.3450$. These parameters were used for maximum likelihood (ML) testing, which was conducted using PhyML 3.0 (Guindon et al. 2010). Bootstrap analysis (100 replicates) was employed to assess the relative robustness of the tree branches. The resulting tree was visualized with FigTree v1.3.1 (Rambaut 2008). Other alignment, including the species described in the present study and additional myxosporean parasites of pimelodids, was used to produce a pairwise similarity matrix using MEGA 5.0.

\section{RESULTS}

Eight of $10(80 \%)$ specimens of Pseudoplatystoma corruscans taken from the São Francisco River had plasmodia of an unknown Henneguya species in the gill filaments.

\section{Henneguya cuniculator sp. nov.}

Description: The plasmodia were white and elongated, followed the line of the gill filaments, and measured up to $1 \mathrm{~cm}$ long (Fig. 1A). Histopathological analysis revealed that the plasmodia developed in the sub-epithelial connective tissue of the gill filaments, and expanded towards the lamellae. Development of the parasite resulted in compression of adjacent tissues, deformation of gill filaments and deformation and fusion of lamellae. Inflammatory infiltrate was not observed in the infection site (Figs. 2 \& 3).
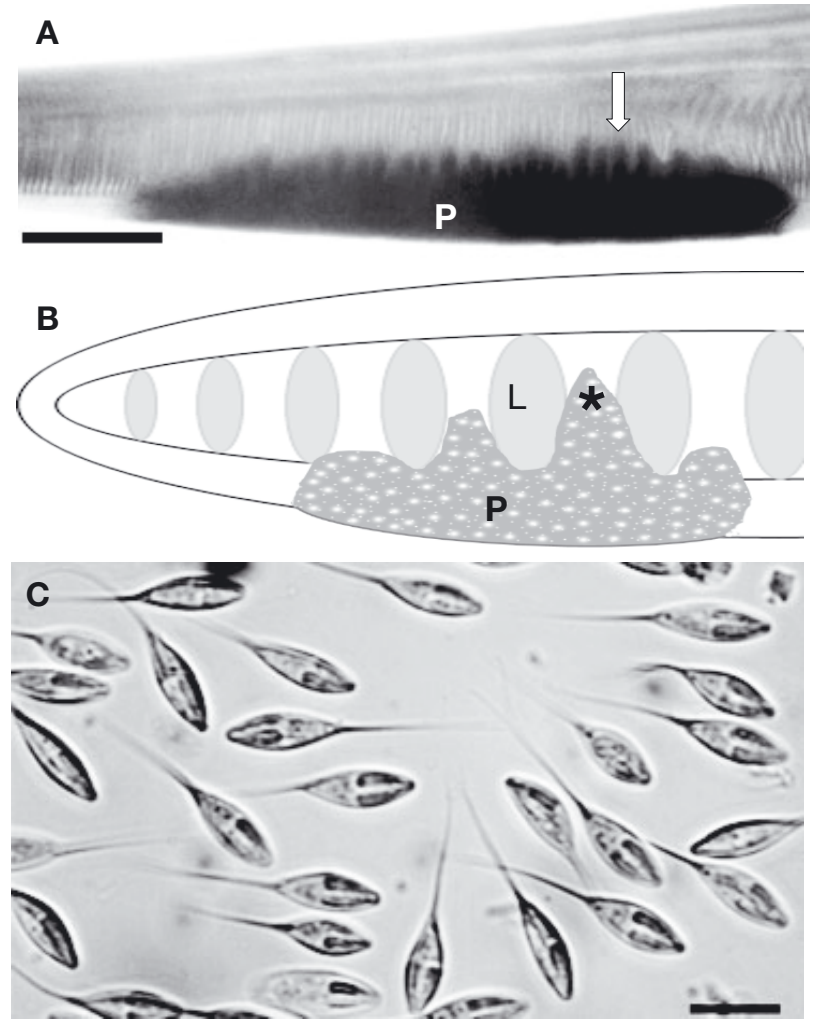

Fig. 1. Henneguya cuniculator sp. nov. infecting Pseudoplatystoma corruscans. (A) Formalin-fixed gill filament showing intrafilamental-epithelial plasmodium (P) growing towards the interlamellar region (arrow). Scale bar $=1000 \mu \mathrm{m}$. (B) Schematic drawing of a gill filament in frontal view showing the development of intrafilamental-epithelial plasmodium $(\mathrm{P})$ growing towards the interlamellar region $(*)$ and causing compression and deformation of the lamellae (L). (C) Mature fresh spores in frontal view. Scale bar $=10 \mu \mathrm{m}$

Mature spores were ellipsoidal from the frontal view, and had a total length of $29.4 \pm 2.4$ (23.3-32.4) $\mu \mathrm{m}$, a body length of $12.1 \pm 1.0(10.0-14.7) \mu \mathrm{m}$, width of $4.8 \pm 0.4(4.0-5.9) \mu \mathrm{m}$, and a caudal process of $16.7 \pm 2.0(12.3-19.4) \mu \mathrm{m}$. From the lateral view, the spores were biconvex and had a thickness of $4.2 \pm$ 0.7 (3.9-4.9) $\mu \mathrm{m}$, while the valves were symmetrical. The polar capsules were elongated and equal in size, and had a length of $6.2 \pm 0.3(5.2-6.2) \mu \mathrm{m}$ and a width of $1.8 \pm 0.1(1.4-1.9) \mu \mathrm{m}$ (Table 1). The polar capsule occupied a little more than half of the body of the spore, and the anterior ends were adjacent (Fig. 1B). The polar filaments had 10 to 11 turns and were arranged perpendicularly to the longitudinal axis of the polar capsule (see Figs. 5B \& 6).

Ultrastructure analysis revealed that the plasmodial wall was formed by a single membrane, and had numerous and extensive pinocytotic canals connecting the outside of the plasmodia to the ectoplasm zone (Fig. 4B). The plasmodial wall had delicate projec- 


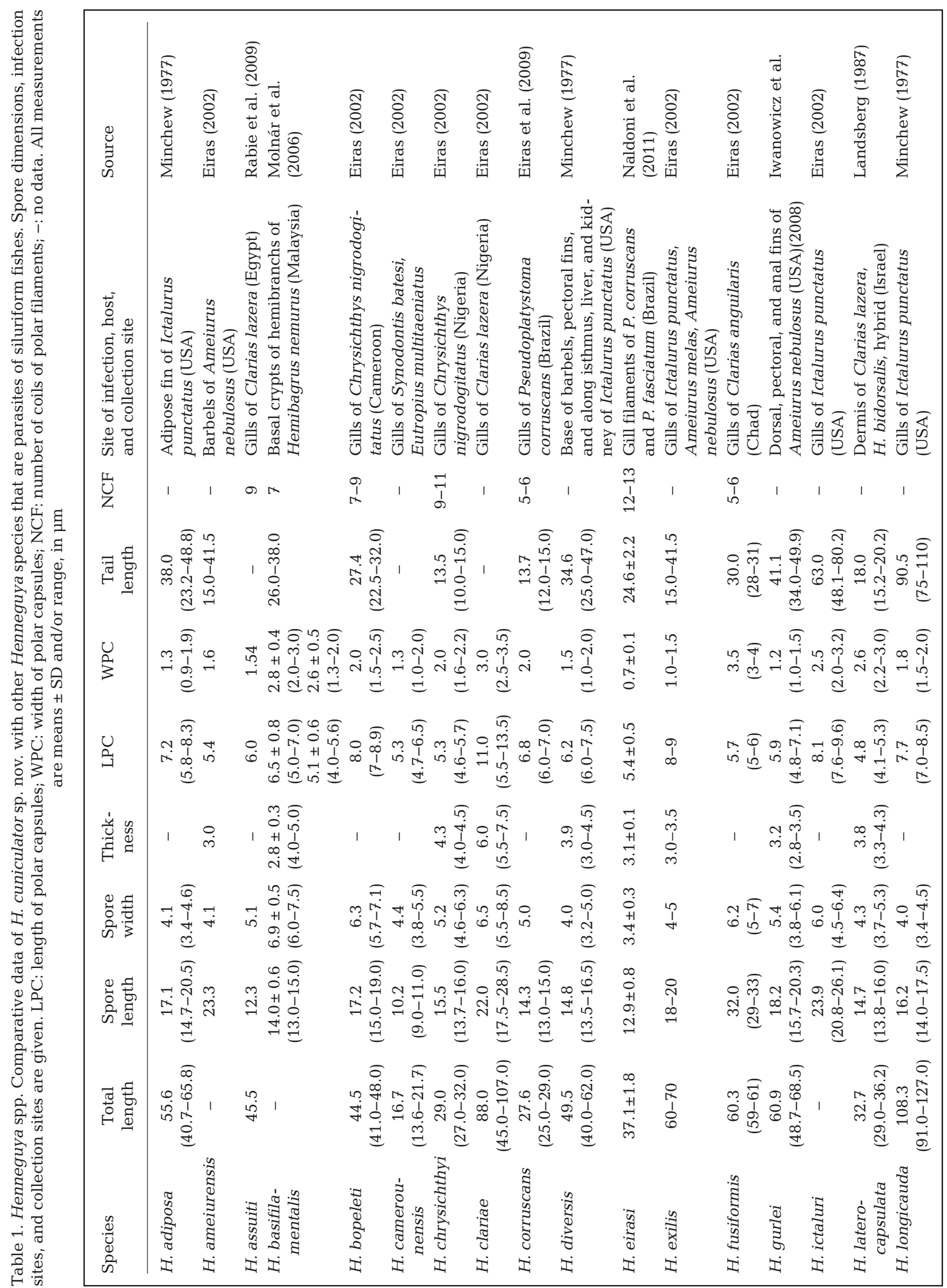




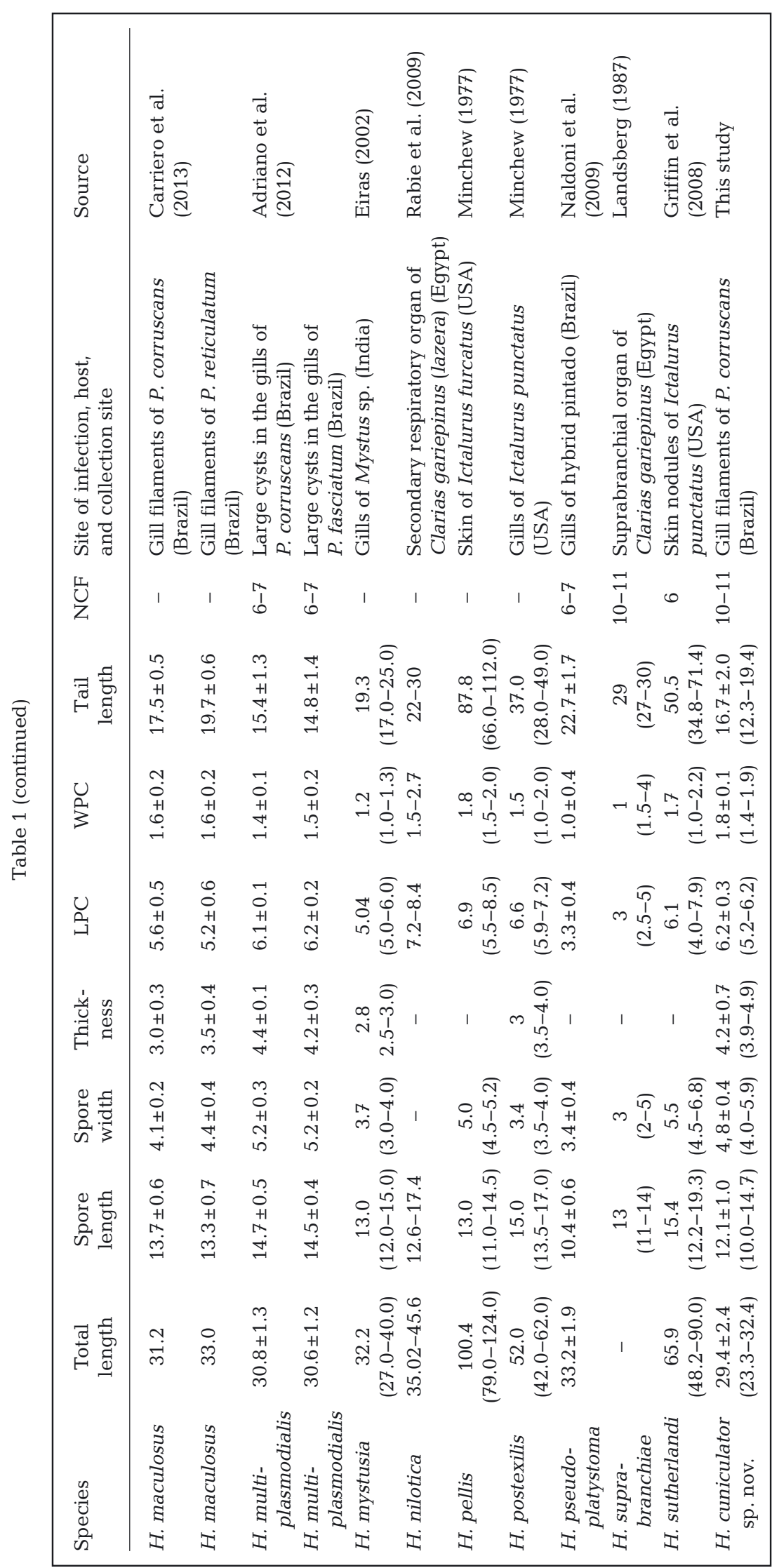

tions towards the host tissue and a thin layer, composed of fine granular material, which prevented contact between the host cells and the plasmodial wall (Fig. 4). A layer of fibrous material was observed throughout the periphery of the plasmodia, and in some cases, this layer of fibrous material was projected toward the interior of the plasmodia (Figs. 4A \& 5A). Few mitochondria were observed underneath the ectoplasm. Below the ectoplasm, generative cells, early stages of sporogenesis, and advanced spore developmental stages were seen. Immature and mature spores were more prevalent internally (Fig. 4).

Molecular analysis, based on 18S rDNA genes from the spores of Henneguya $\mathrm{Cu}$ niculator sp. nov. obtained from the gills of Pseudoplatystoma corruscans, resulted in a $1200 \mathrm{bp}$ sequence that did not match any myxosporean species sequences available in GenBank. Analysis of the genetic divergence of the Henneguya species that parasitize Pseudoplatystoma spp. showed that the closest species to $H$. cuniculator sp. nov. was $H$. multiplasmodialis $(1.7 \%$ divergence from that found infecting $P$. reticulatum and $1.8 \%$ from that found in P. corruscans), and the most distant was H. maculosus (13.1\%) (Table 2).

Phylogenetic analysis, using only Henneguya/Myxobolus species parasites of siluriforms, formed 2 distinct strains. Clade A clustered 2 Henneguya species that parasitize fish of the Bagridae family. M. cordeiroi, a parasite of the pimelodid Zungaru jahu, appeared as a sister branch of the large clade $B$, which comprised Henneguya/Myxobolus parasites of pimelodids, ictalurids, and pangasids. Clade B further divided to form a sub-clade composed only of Henneguya species parasites of pimelodids of the genus Pseudoplatystoma and another composed of Henneguya species that parasitize ictalurids. M. pangasii and M. hackyi clustered together as a basal branch of the clade formed by parasites of ictalurids, and $M$. flavus, the unique Myxobolus species parasite of fish of the genus Pseudoplatystoma, appears as a basal branch of clade B. (Fig. 7). 


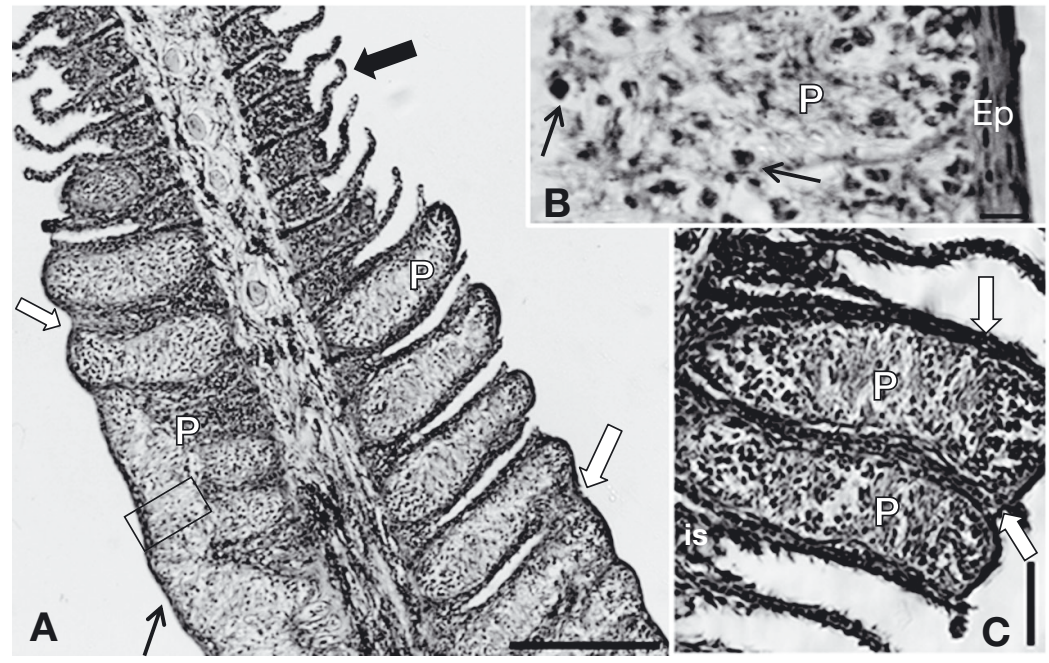

Fig. 2. Pseudoplatystoma corruscans infected by Henneguya cuniculator sp. nov. Light photomicrographs of histological sections of gill filaments. (A) Plasmodium (P) in sub-epithelial connective tissue (thin black arrow) occupying all area of the filament. Note normal lamellae (thick black arrow) and several deformed lamellae and lamellar fusion in areas affected by the growth of the plasmodium (white arrows). Scale bar $=200 \mu \mathrm{m}$. (B) Magnified section (rectangle) from (A); note the asynchronous process of sporogony inside the plasmodium (P), with young developmental stage spores (arrows) spread across all areas of the plasmodium. Ep: epithelium. Scale bar $=20 \mu \mathrm{m}$. (C) Detail of the development of plasmodium (P) growing towards the interlamellar regions occupying the entire interlamellar space (is) and causing deformation and compression of the lamellae (white arrows). Scale bar $=50 \mu \mathrm{m}$
Host type: Pseudoplatystoma corruscans.

Specimens deposited: One slide containing spores fixed with methanol, stained with Giemsa stain solution, and mounted in a low-viscosity mounting medium, was deposited in the collection of the Museum of Natural History, Institute of Biology, Universidade Estadual de Campinas, state of São Paulo, Brazil (accession nos. ZUEC MYX 40 and ZUEC MYX 41). The 18S rDNA sequence was deposited in GenBank under accession number KF732840.

Locality: São Francisco River, municipality of Pirapora, state of Minas Gerais, Brazil.

Etymology: People born in the state of Minas Gerais are known in Portuguese as 'mineiros' ('miners') in reference to the widespread mining activity that developed in the region during the 17th and 18th centuries. 'Cuniculator' means 'miner' in Latin. Therefore the specific name is related to the place where the parasite was found.

\section{DISCUSSION}

Six myxosporeans have been found to infect the gills of fish of the genus Pseudoplatystoma. Henneguya pseudoplatystoma was found infecting gill filaments of pintado hybrids from fish farms, causing stretching and deformation of these structures, leading to a reduction of the functional area of the epithelium (Naldoni et al. 2009). H. eirasi was found parasitizing gill filaments of $P$. corruscans and $P$. reticulatum from natural environments in the Brazilian Pantanal wetland, and produced only slight compression of the adjacent tissues (Naldoni et al. 2011). $H$. corruscans was described infecting the gill lamellae from $P$. corruscans from natural environments in the Paraná River and caused hypertrophy of the infected lamella (Eiras et al. 2009). H. multiplasmodialis was found forming large plasmodia on the surface of the gills of $P$. corruscans and $P$. reticulatum from the Brazilian Pantanal wetland. The plasmodia of this species were arranged unusually, being externally enveloped by a stratified epithelium composed of several cell types, with a predominance of mucus
Prevalence: 8 of the 10 specimens (80\%) of Pseudoplatystoma corruscans were infected.

Site of infection: gill filaments.

Fig. 3. Pseudoplatystoma corruscans infected by Henneguya cuniculator sp. nov. Light photomicrograph of histologica of the interlamellar epithelium (*) with agglomerated nuclei of epithelial cells (thin white arrow), deformation of the lamellae (thick black arrows), and young developmental spores (thick white arrows) spread across all areas of the plasmodium (P). Scale bar $=50 \mu \mathrm{m}$ 


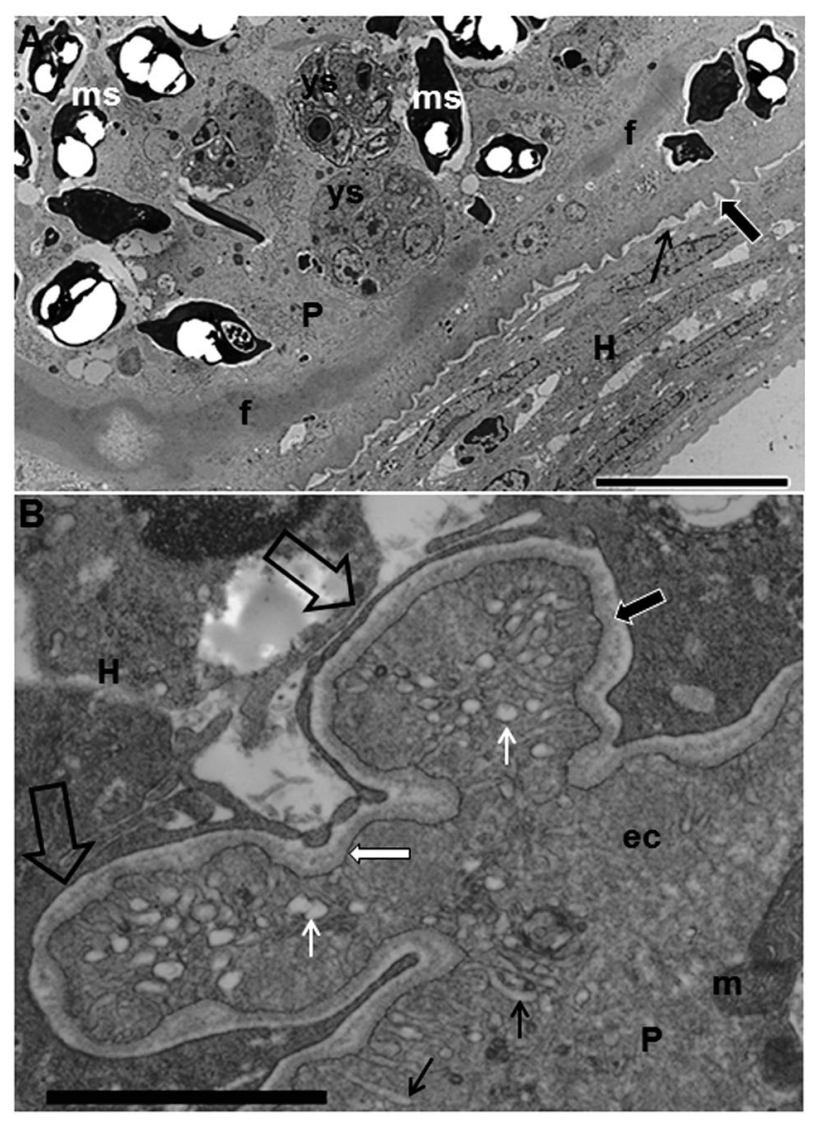

Fig. 4. Pseudoplatystoma corruscans infected by Henneguya cuniculator sp. nov. Electron micrograph of gill filaments. (A) Host-parasite interface showing host tissue (H) separated from plasmodium by a layer of fine granular material (thin arrow) and delicate projections of the plasmodial wall (thick arrow). Note the presence of a layer of fibrous material (f) in the periphery of the plasmodium, young sporoblasts (ys), and mature spores (ms). Scale bar $=10 \mu \mathrm{m}$. (B) Amplified portion of the host-parasite interface showing the projection of plasmodial expansion (empty arrows) toward the host tissue $(\mathrm{H})$ and a layer of granular material (thick black arrow) separating the plasmodial (P) from the host cells. Note the single plasmodial membrane (thick white arrow) with numerous pinocytic channels (thin black arrows) toward the ectoplasm zone (ec) and ending in pinocytic vesicles (thin white arrows). Scale bar $=2 \mu \mathrm{m}$

and club cells. Internally, the plasmodia were composed of a network of septa formed by connective tissue, dividing the plasmodium into compartments, with inflammatory infiltrate in the tissue surrounding the plasmodium, as well as in the septa (Adriano et al. 2012). H. maculosus was found in the gill filaments and $M$. flavus in the gill arch (Carriero et al. 2013) of fish from the Brazilian Pantanal wetland, but histological analysis was not performed. In the species analyzed in the present study, histological analysis revealed the development of the plasmodia in the sub-epithelial connective tissue of the gill filaments,
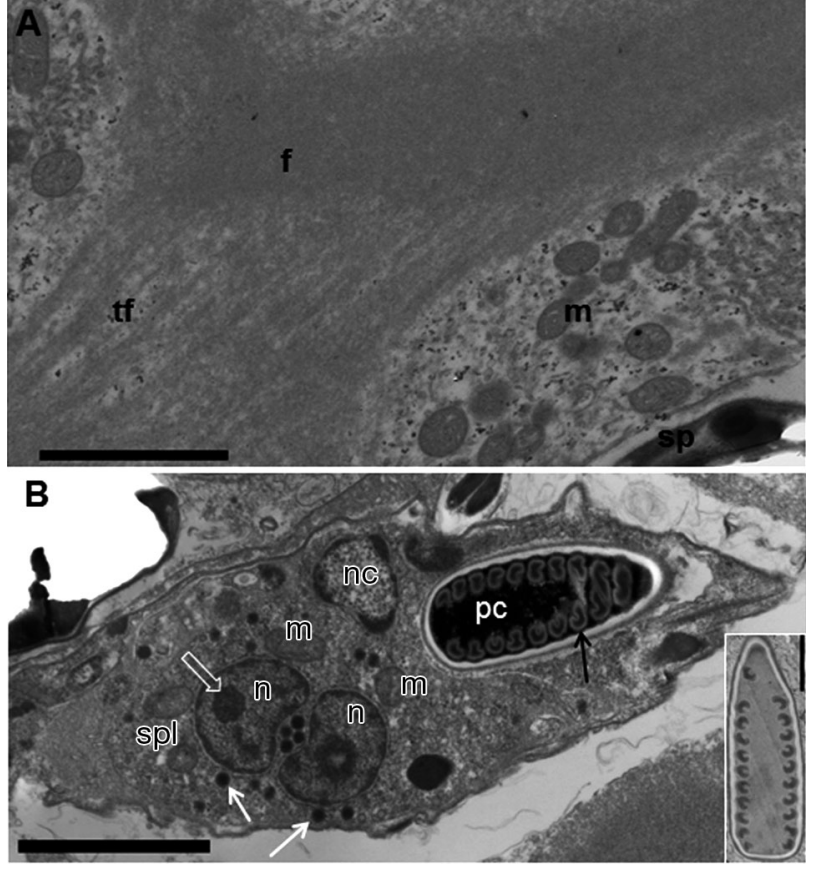

Fig. 5. Henneguya cuniculator sp. nov. infecting Pseudoplatystoma corruscans. Electron micrograph of plasmodium of $H$. cuniculator sp. nov. parasitizing gill filaments of $P$. corruscans. (A) Details of layer of fibrous material (f) of the periphery of the plasmodia showing thin fibriles (tf), mitochondria (m), and part of a spore. Scale bar $=5 \mu \mathrm{m}$. (B) Longitudinal section of a young spore showing sporoplasm binucleate with nucleoli ( $\mathrm{n}$, empty arrow), sporoplasmosomes (spl, white arrows), and several mitochondria (m); polar capsule (pc) with polar filaments (black arrow) and nucleus of the capsulogenic cell (nc). Scale bar $=2.5 \mu \mathrm{m}$. On the right is a longitudinal section of a whole polar capsule showing the number of turns of the polar filament. Scale bar $=1 \mu \mathrm{m}$

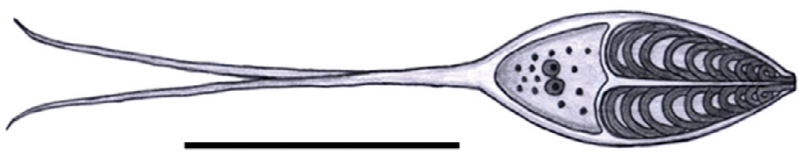

Fig. 6. Henneguya cuniculator sp. nov. Schematic representation of the mature spore of $H$. cuniculator sp. nov., a parasite of Pseudoplatystoma corruscans. Scale bar $=10 \mu \mathrm{m}$

producing compression of the adjacent tissues, deformation of the gill filaments, and lamellar fusion, leading to the reduction of the functional epithelium area in a similar manner to $H$. pseudoplatystoma (Naldoni et al. 2009). However, as observed for H. corruscans, $H$. pseudoplatystoma, and $H$. eirasi, inflammatory infiltrate was not found at the infection site.

Ultrastructural analysis of the host-parasite interface of Henneguya cuniculator sp. nov. showed a thin 
Table 2. Henneguya spp. Pairwise genetic identity of the 18S rRNA gene of $H$. cuniculator sp. nov. and related Henneguya species that are parasites of fish of the genus Pseudoplatystoma. The area above the diagonal shows nucleotide differences in relation to the number of bases compared. The area below the diagonal shows \% pairwise distance identity

\begin{tabular}{|llrrrrrrrr|}
\hline \multicolumn{2}{l}{ Species } & 1 & 2 & 3 & 4 & 5 & 6 & 7 \\
\hline 1 & H. cuniculator sp. nov. & - & $18 / 1030$ & $22 / 1214$ & $53 / 1215$ & $50 / 1214$ & $107 / 915$ & $136 / 1222$ & $156 / 1206$ \\
2 & H. multiplasmodialis (P. reticulatum) & 1.7 & - & $11 / 1316$ & $82 / 1315$ & $85 / 1315$ & $184 / 1329$ & $208 / 1340$ & $213 / 1330$ \\
3 & H. multiplasmodialis (P. corruscans) & 1.8 & 0.8 & - & $109 / 1559$ & $109 / 1562$ & $187 / 1210$ & $241 / 1592$ & $268 / 1507$ \\
4 & H. corruscans (P. corruscans) & 4.2 & 6.3 & 7.0 & - & $44 / 1895$ & $193 / 1206$ & $259 / 1938$ & $273 / 1504$ \\
5 & H. corruscans (P. reticulatum) & 4.1 & 6.5 & 7.0 & 2.3 & - & $202 / 1206$ & $266 / 1924$ & $269 / 1505$ \\
6 & H. eirasi (P. reticulatum) & 11.8 & 15.6 & 15.9 & 16.4 & 17.1 & - & $111 / 1209$ & $116 / 1209$ \\
7 & H. maculosus (P. corruscans) & 11.3 & 15.9 & 15.5 & 13.7 & 14.1 & 9.2 & - & $29 / 1496$ \\
8 & H. maculosus (P. reticulatum) & 13.1 & 16.4 & 18.0 & 18.4 & 18.1 & 9.7 & 1.9 & - \\
\hline
\end{tabular}

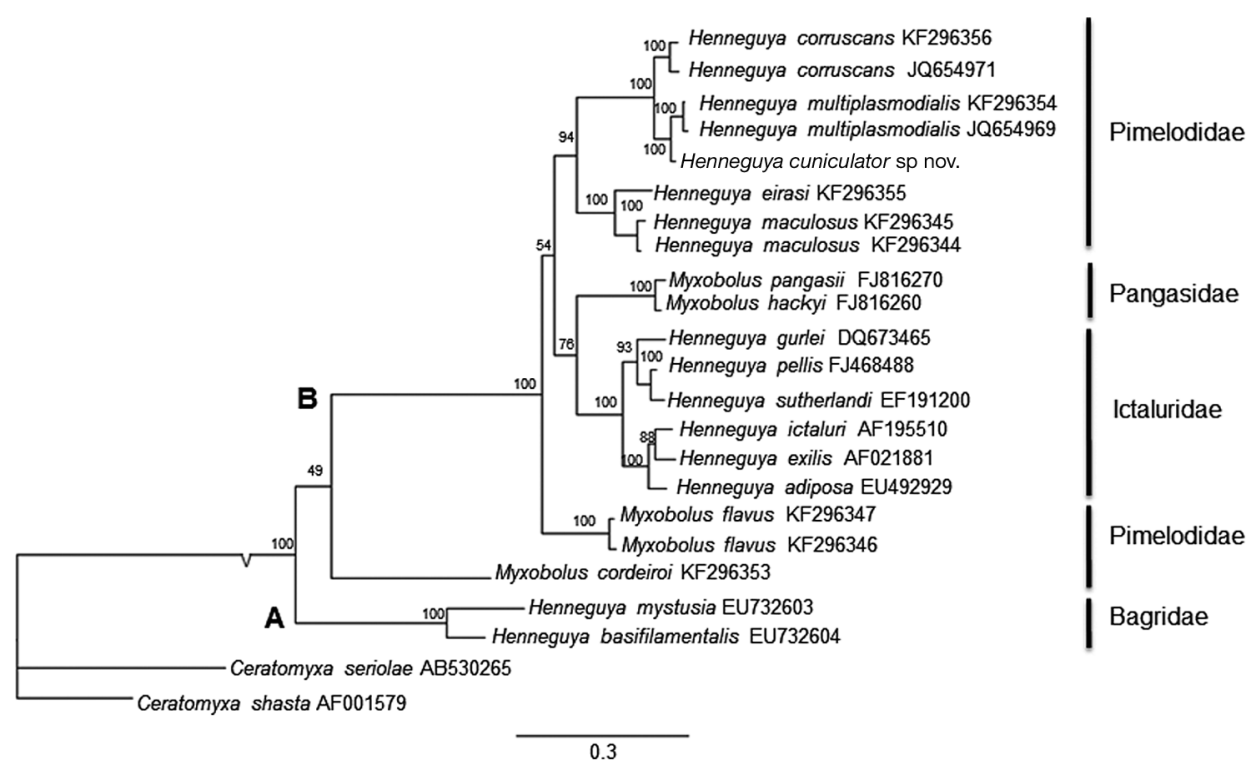

Fig. 7. Henneguya spp. and Мyхоbolus spp. Maximum likelihood tree showing relationship between $H$. cuniculator sp. nov. and other Henneguya and Myxobolus species that are parasites of siluriform fish based on the 18S rDNA gene. Numbers above nodes indicate bootstrap confidence levels; A and B mark branch points defining clades A and B

layer of fine granular material preventing contact between the plasmodium and the host tissue, while numerous pinocyte canals connected the outside of the plasmodia to the ectoplasm zone, demonstrating the intense nutritional activity of the plasmodium. The plasmodial wall of $H$. cuniculator sp. nov., which was comprised of a single membrane, also presented delicate projections towards the host tissue, seemingly seeking increased surface contact with the host tissue, a mechanism related to nutritional activity, as also observed by Naldoni et al. (2009) and El-Mansy \& Bashtar (2002). The sporogenesis process of $H$. $\mathrm{cu}$ niculator sp. nov. was similar to those observed in other species of Henneguya (Matos et al. 2005, Ali et al. 2007, Abdel-Ghaffar et al. 2008, Azevedo et al. 2008, Naldoni et al. 2009, 2011, Barassa et al. 2012). However, the plasmodia of $H$. cuniculator sp. nov. presented a conspicuous layer of slightly electrondense fibrous material spreading throughout the periphery. This material is similar to that observed in the periphery of $H$. pseudoplatystoma and $H$. eirasi
(Naldoni et al. 2009, 2011). According to Naldoni et al. (2009), this electron-dense fibrous material corresponds to actin filaments and may play a role in the support of the plasmodium. Fibrous material resembling aggregated actin anchoring the mural cells of the presporogonic cells of the malacosporean Tetracapsuloides bryosalmonae was also reported by Morris \& Adams (2007). The presence of microfilaments in the developmental stages of myxosporeans was also reported by Casal et al. (1997), who identified myosin filaments occupying the space of pericyte cells of $H$. striolata Casal et al. 1997.

The morphologic and morphometric characteristics of Henneguya cuniculator sp. nov. were compared with those of all Henneguya spp. that parasitize siluriform fish (Eiras 2002, Rabie et al. 2009, Eiras \& Adriano 2012). Spores of the species $H$. multiplasmodialis, H. maculosus, H. corruscans, H. suprabranchiae Landsberg, 1987, and H. nilotica Marwan, 1998 had a higher morphometric and morphologic resemblance to those of $H$. cuniculator sp. nov. Nevertheless, a 
small number of subtle morphologic differences were observed, such as spore body length $(12.1 \mu \mathrm{m}$ for $H$. cuniculator sp. nov.; 13.3 and $13.7 \mu$ for $H$. maculosus, 14.5 and $14.7 \mu \mathrm{m}$ for $H$. multiplasmodialis, and $14.3 \mu \mathrm{m}$ for $H$. corruscans) and the number of turns of the polar filaments (10 to 11 turns in $H$. cuniculator sp. nov., 6 to 7 turns in $H$. multiplasmodialis and $H$. maculosus, and 5 to 6 turns in H. corruscans). Differences may also be observed in the length of the polar capsules $(6.2 \mu \mathrm{m}$ for $H$. cuniculator sp. nov. and $3 \mu \mathrm{m}$ for $H$. suprabranchiae) and in tail length (16.7 $\mu \mathrm{m}$ for $H$. cuniculator sp. nov; $13.7 \mu \mathrm{m}$ for $H$. corruscans; 22 to $30 \mu \mathrm{m}$ for $H$. nilotica, and $29 \mu \mathrm{m}$ for H. suprabranchiae; detailed morphometric data are displayed in Table 1). Other important differences observed relate to the host, location of infection sites, and appearance of the plasmodia, which were small and in the gill lamellae in case of $H$. corruscans (Eiras et al. 2009) and large and on the gill surface in case of H. multiplasmodialis (Adriano et al. 2012), while the plasmodia of $H$. cuniculator sp. nov. were located in the internal areas of the gill filaments. H. suprabranchiae infects the hyaline cartilage of the suprabranchial organ of Clarias gariepinus (Burchell, 1822) (El-Mansy \& Bashtar 2002) and H. nilotica forms spherical plasmodia in the tips of the suprabranchial organ of C. lazera Valenciennes, 1840 (junior synonym of C. gariepinus) (Rabie et al. 2009).

Geography should also be considered. Pseudoplatystoma corruscans is known to inhabit rivers from the La Plata and São Francisco basins (Resende 2003). However, in phylogenetic studies of Pseudoplatystoma species, based on analysis of cytochrome $b$ mtDNA sequences, Carvalho-Costa et al. (2011) showed the existence of geographically distinct clades for $P$. corruscans, with the samples from the São Francisco and La Plata Basins being clearly separated. According to those authors, P. corruscans haplotypes from the São Francisco Basin are on average $1.5 \%$ divergent from the populations from the $\mathrm{La}$ Plata Basin. The authors also pointed out that these genetic differences suggest a substantial period of evolutionary divergence and speculated that such divergence may be related to reproductive isolation, since these populations have been geographically separated for a considerable time. In this same way, geography may also contribute to the divergence of these parasites, as Henneguya cuniculator sp. nov. infects $P$. corruscans from the São Francisco Basin, while $H$. multiplasmodialis, $H$. maculosus, and $H$. corruscans were described in $P$. corruscans and $P$. reticulatum taken from rivers from the La Plata Basin.
There is no exact value that defines at what point a difference in the 18S rDNA genes of a myxozoan species should be considered as intra- or interspecific variation (Gunter \& Adlard 2009). However, according to Cech et al. (2012), identity values close to $100 \%$ undoubtedly indicate that the 2 species are identical, but a $98-99 \%$ sequence identity makes it difficult to decide whether a single or multiple species are being considered. The comparison of the 18S rDNA gene sequences from Henneguya cuniculator sp. nov. with H. multiplasmodialis in Pseudoplatystoma spp. shows genetic divergence of $1.7-1.8 \%$ (Table 2 ). The small genetic divergence observed between $H$. cuniculator sp. nov. and $H$. multiplasmodialis is not robust enough to be defined as an interspecific variation and would not by itself be strong enough to separate these 2 Henneguya species. On the other hand, this genetic divergence, when added to other data such as site of parasite development, the histologic appearance of the plasmodia, differences in spore characteristics (smaller spore body length and higher number of polar filaments turns in $H$. cuniculator sp. nov.), strongly support the separation of these species. Another important aspect to be considered here is the extended period of geographical isolation of the La Plata and São Francisco Basins, which can play a decisive role in genetic divergence, as observed by Carvalho-Costa et al. (2011) in the $P$. corruscans populations from these 2 basins. Based on such morphologic, molecular, and geographic arguments, we believe that there is enough evidence to support the creation of new species.

The phylogenetic studies of the sequences of Henneguya and Myxobolus available in the GenBank database illustrate a general tendency to group according to the taxonomic affinities of the host fish (Ferguson et al. 2008, Naldoni et al. 2011, Adriano et al. 2012, Carriero et al. 2013). Thus, in the present study, phylogenetic analysis was performed only for Henneguya/Myxobolus species that are parasites of siluriform fish. The results showed that the grouping of Henneguya/Myxobolus exactly followed the family of host fish, corroborating the hypothesis of a notably close relationship between the evolution of Henneguya/Myxobolus parasites and their hosts.

Acknowledgements. We thank J. L. Bartholomew (Center for Fish Disease Research of the Department of Microbiology, Oregon State University) for undertaking a critical reading of the manuscript and the anonymous reviewers for their suggestions, which helped to improve this article. Financial support was received from CNPq (Proc. no. 472747/2012-6). J.N. was supported by a FAPESP scholarship (Proc. no. 2011/10738-1). 


\section{LITERATURE CITED}

Abdel-Ghaffar F, Abdel-Baki AS, Bayoumy EM, Bashtar AR and others (2008) Light and electron microscopic study on Henneguya suprabranchiae Landsberg, 1987 (Myxozoa: Myxosporea) infecting Oreochromis niloticus, a new host record. Parasitol Res 103:609-617

- Adriano EA, Carriero MM, Maia AAM, Silva MRM, Naldoni J, Ceccarelli OS, Arana S (2012) Phylogenetic and hostparasite relationship analysis of Henneguya multiplasmodialis n. sp. infecting Pseudoplatystoma spp. in Brazilian Pantanal wetland. Vet Parasitol 185:110-120

> Ali MA, Abdel-Baki AS, Sakran Th, Entzeroth R, AbdelGhaffar F (2007) Myxobolus lubati n. sp. (Myxosporea: Myxobolidae), a new parasite of haffara seabream Rhabdosargus haffara (Forsskal, 1775), Red Sea, Egypt: a light and transmission electron microscopy. Parasitol Res 100: 819-827

Altschul SF, Madden TL, Schaffer AA, Zhang J, Zhang Z, Miller W, Lipman DJ (1997) Gapped BLAST and PSIBLAST: a new generation of protein database search programs. Nucleic Acids Res 25:3389-3402

> Azevedo C, Casal G, Matos P, Matos E (2008) A new species of Myxozoa, Henneguya rondoni n. sp. (Myxozoa), from the peripheral nervous system of the Amazonian fish, Gymnorhamphichthys rondoni (Teleostei). J Eukaryot Microbiol 55:229-234

> Barassa B, Adriano EA, Cordeiro NS, Ceccarelli PS (2012) Morphology and host-parasite interaction of Henneguya azevedoi n. sp., parasite of gills of Leporinus obtusidens from Mogi-Guaçu River, Brazil. Parasitol Res 110: 887-894

- Barta JR, Martin DS, Liberato PA, Dashkevicz M and others (1997) Phylogenetic relationships among eight Eimeria species infecting domestic fowl inferred using complete small subunit ribosomal DNA sequences. J Parasitol 83: $262-271$

Campos JL (2005) O cultivo do pintado, Pseudoplatystoma corruscans (Spix \& Agassiz 1829). In: Baldisserotto B, Gomes LC (eds) Espécies nativas para piscicultura no Brasil. UFSM, Santa Maria, p 327-343

Carriero MM, Adriano EA, Silva MRM, Ceccarelli PS, Maia AAM (2013) Molecular phylogeny of the Myxobolus and Henneguya genera with several new South American species. PLoS ONE 8:e73713

> Carvalho-Costa LF, Piorski NM, Willis SC, Galetti PM Jr, Ortí G (2011) Molecular systematics of the neotropical shovelnose catfish genus Pseudoplatystoma Bleeker 1862 based on nuclear and mtDNA markers. Mol Phylogenet Evol 59:177-194

> Casal G, Matos E, Azevedo C (1997) Some ultrastructural aspects of Henneguya striolata sp. nov. (Myxozoa, Myxosporea), a parasite of the Amazonian fish Serrasalmus striolatus. Parasitol Res 83:93-95

> Cech G, Molnár K, Székely C (2012) Molecular genetic studies on morphologically indistinguishable Myxobolus spp. infecting cyprinid fishes, with the description of three new species, $M$. alvarezae sp. nov., $M$. sitjae sp. nov. and M. eirasianus sp. nov. Acta Parasitol 57:354-366

> Diamant A, Whipps CM, Kent ML (2004) A new species of Sphaeromyxa (Myxosporea: Sphaeromyxina: Sphaeromyxidae) in devil firefish, Pterois miles (Scorpaenidae), from the northern Red Sea: morphology, ultrastructure, and phylogeny. J Parasitol 90:1434-1442

Eiras JC (2002) Synopsis of the species of the genus Henne- guya Thelohan, 1892 (Myxozoa: Myxosporea: Myxobolidae). Syst Parasitol 52:43-54

Eiras JC, Adriano EA (2012) A checklist of new species of Henneguya Thelohán, 1892 (Myxozoa: Myxosporea, Myxobolidae) described between 2002 and 2012. Syst Parasitol 83:95-104

> Eiras JC, Takemoto RM, Pavanelli GC (2009) Henneguya corruscans n. sp. (Myxozoa, Myxosporea, Myxobolidae), a parasite of Pseudoplatystoma corruscans (Osteichthyes, Pimelodidae) from the Parana River, Brazil: a morphological and morphometric study. Vet Parasitol 159:154-158

> El-Mansy A, Bashtar AR (2002) Histopathological and ultrastructural studies of Henneguya suprabranchiae Landsberg 1987 (Myxosporea; Myxobolidae) parasitizing the suprobranchial organ of the freshwater catfish Clarias gariepinus Burchell 1822 in Egypt. Parasitol Res 88: $617-626$

- Eszterbauer E (2004) Genetic relationship among gillinfecting Myxobolus species (Myxosporea) of cyprinids: molecular evidence of importance of tissue-specificity. Dis Aquat Org 58:35-40

> Ferguson JA, Atkinson SD, Whipps CM, Kent ML (2008) Molecular and morphological analysis of Myxobolus spp. of salmonid fishes with the description of a new Мухоbolus species. J Parasitol 94:1322-1334

Froese R, Pauly D (2011) FishBase. www.fishbase.org (accessed on 5 March 2013)

> Griffin MJ, Pote LM, Wise DJ, Greenway TE, Mauel MJ, Camus AC (2008) A novel Henneguya species from channel catfish described by morphological, histological, and molecular characterization. J Aquat Anim Health 20:127-135

> Guindon S, Dufayard JF, Lefort V, Anisimova M, Hordijk W, Gascuel O (2010) New algorithms and methods to estimate maximum-likelihood phylogenies: assessing the performance of PhyML 3.0. Syst Biol 59:307-321

> Gunter NL, Adlard RD (2009) Seven new species of Ceratomyxa Thelohan, 1892 (Myxozoa) from the gall-bladders of serranid fishes from the Great Barrier Reef, Australia. Syst Parasitol 73:1-11

Hall TA (1999) BioEdit: A user-friendly biological sequence alignment editor and analysis program for Windows 95/98/NT. Nucleic Acids Symp Ser 41:95-98

- Hallett SL, Diamant A (2001) Ultrastructure and smallsubunit ribosomal DNA sequence of Henneguya lesteri n. sp. (Myxosporea), a parasite of sand whiting Sillago analis (Sillaginidae) from the coast of Queensland, Australia. Dis Aquat Org 46:197-212

> Iwanowicz LR, Iwanowicz DD, Pote LM, Blazer VS, Schill WB (2008) Morphology and 18S rDNA of Henneguya gurlei (Myxosporea) from Ameiurus nebulosus (Siluriformes) in North Carolina. J Parasitol 94:46-57

Landsberg JH (1987) Myxosporean parasites of the catfish, Clarias lazera (Valenciennes). Syst Parasitol 9:73-81

Mar \& Terra (2013) Our production process: logistics and transportation. Available at www. mareterra.com.br/site 2013/empresa.asp?lang=in (accessed on 5 March 2013)

Matos E, Tajdari J, Azevedo C (2005) Ultrastructural studies of Henneguya rhamdia n. sp. (Myxozoa) a parasite from the Amazon teleost fish, Rhamdia quelen (Pimelodidae). J Eukaryot Microbiol 52:532-537

> Minchew CD (1977) Five new species of Henneguya (Protozoa: Myxosporida) from ictalurid fish. J Protozool 24: 213-220

- Molnár K, Székely C, Mohamed K, Shaharom-Harrison F (2006) Myxozoan pathogens in cultured Malaysian 
fishes. I. Myxozoan infections of the sutchi catfish Pangasius hypophthalmus in freshwater cage cultures. Dis Aquat Org 68:209-218

Morris DJ, Adams A (2007) Sacculogenesis and sporogony of Tetracapsuloides bryosalmonae (Myxozoa: Malacosporea) within the bryozoan host Fredericella sultana (Bryozoa: Phylactolaemata). Parasitol Res 100:983-992

MPA (Ministério da Pesca e Aqüicultura) (2012) Boletim estatístico da pesca e aquicultura. MPA, Brasília

Naldoni J, Arana S, Maia AAM, Ceccarelli PS and others (2009) Henneguya pseudoplatystoma n. sp. causing reduction in epithelial area of gills in the farmed pintado, a South American catfish: histopathology and ultrastructure. Vet Parasitol 166:52-59

Naldoni J, Arana S, Maia AAM, Silva MRM and others (2011) Host-parasite-environment relationship, morphology and molecular analysis of Henneguya eirasi n.

Editorial responsibility: Sven Klimpel,

Frankfurt, Germany sp. parasite of two wild Pseudoplatystoma ssp. in Pantanal Wetland, Brazil. Vet Parasitol 177:247-255

Posada D (2008) JModelTest: phylogenetic model averaging. Mol Biol Evol 25:1253-1256

Rabie SA, Mohammed NI, Hussein AA, Hussein NM (2009) The infection of freshwater fishes with three species of Henneguya in Qena, Upper Egypt. Egypt Acad J Biol Sci 1:11-19

Rambaut A (2008) FigTree v1.1.1: Tree figure drawing tool. Available from: http://tree.bio.ed.ac.uk/software/figtree/

Resende EK (2003) Migratory fishes of the ParaguayParaná Basin excluding the upper Paraná Basin. In: Carolsfeld J, Harvey B, Ross C, Baer A (eds) Migratory fishes of South America: biology, fisheries and conservation status. World Fisheries Trust, The World Bank, and International Development Research Center, Ottawa, p 99

Submitted: May 6, 2013; Accepted: October 15, 2013 Proofs received from author(s): December 19, 2013 